WMJ (Warmadewa Medical Journal), Vol. 5 No. 1 Mei 2020, Hal. 8-15

\title{
Physical, Chemical, and Biological Water Quality Characteristics of Buyan Lake and Tamblingan Lake
}

\author{
Ni Made Hegard Sukmawati ${ }^{1}$, Ni Wayan Rusni ${ }^{2}$, Anny Eka Pratiwi ${ }^{3}$ \\ ${ }^{1,2,3}$ Fakultas Kedokteran dan Ilmu Kesehatan Universitas Warmadewa \\ Email : sukmawati.hegard@gmail.com
}

\begin{abstract}
Buyan Lake and Tamblingan Lake are known as twin lakes in Bali which serve not only as water sources for agriculture and households, but also as tourist destinations. Infrastructure development and the upsurge of tourism activities potentially increase the contamination of lake water in Bali. The aim of this study was to investigate the quality of water in Buyan Lake and Tamblingan Lake based on physical, chemical, and biological parameters. Five sampling sites (stations) were purposively chosen in each of the lakes. Physical parameters (temperature and total dissolved solids) and chemical parameters (dissolve oxygen, biochemical oxygen demand, chemical oxygen demand, $\mathrm{pH}$, phosphate, ammonia, nitrate, and heavy metal) were measured from each station. Coliform and fecal coli were also tested to assess biological contamination. The level of contamination were compared to the Bali Governor Regulation no 16 Year 2016 on Water Quality Management and Pollution Control. Among 14 parameters being measured on Buyan Lake water samples, two of them did not meet the standard water quality 1 : BOD $(2.19 \pm 0.64 \mathrm{mg} / \mathrm{l})$ and COD $(49.18 \pm 28.70 \mathrm{mg} / \mathrm{l})$. While, water samples from Tamblingan Lake had 3 parameters above the standard water quality 1: COD (62.92 \pm 17.93 $\mathrm{mg} / \mathrm{l})$, phosphate $(0.23 \pm 0.19 \mathrm{mg} / \mathrm{l})$, and coliform $(3319 \pm 7090 \mathrm{MPN} / 100 \mathrm{ml})$. In general, water samples from both lakes did not meet the criteria for potable water neither for recreational activities. High COD in both lakes indicated high organic contaminants.
\end{abstract}

Keywords: Buyan, lake, Tamblingan, water

\section{Abstrak}

[Kualitas Fisika, Kimia dan Biologi Air Danau Buyan dan Tamblingan]

Danau Buyan dan Danau Tamblingan dikenal sebagai danau kembar di Bali yang tidak hanya berfungsi sebagai sumber air bagi aktivitas pertanian dan pemukiman, melainkan pula sebagai objek wisata. Pengembangan sarana pariwisata dan peningkatan jumlah aktivitas kepariwisataan berpotensi meningkatkan pencemaraan air danau Buyan dan Tamblingan. Penelitian ini bertujuan untuk mengetahui kualitas air danau di Danau Buyan dan Danau Tamblingan menurut parameter fisika, kimia dan biologi. Lima titik sampling (station) air dipilih secara purposif di area dekat akses masuk di kedua danau. Parameter yang diukur meliputi parameter fisika (temperatur dan residu terlarut), kimia (DO, BOD $5, C O D, p H$, fosfat, amoniak, nitrat, dan logam berat) dan biologi (coliform dan fecal coliform). Hasil pemeriksaan dibandingkan dengan baku mutu air berdasarkan Peraturan Gubernur Bali No 16 Tahun 2016 tentang Pengelolaan Kualitas Air dan Pengendalian Pencemaraan Air. Dari 14 parameter kualitas air yang diukur pada penelitian ini, terdapat 2 parameter yang belum memenuhi baku mutu kelas 1 untuk Danau Buyan yakni BOD (2,19 \pm 0,64 mg/l) dan COD $(49,18 \pm 28,70 \mathrm{mg} / \mathrm{l})$. Sedangkan pada air Danau Tamblingan terdapat 3 parameter yang tidak memenuhi baku mutu kelas 1, yakni COD (62,92 \pm 17,93 mg/l), fosfat (0,23 \pm 0,19 mg/l), dan coliform (3319 \pm 7090 MPN/100 ml). Secara umum, air Danau Buyan maupun Tamblingan tidak memenuhi kualitas baku air minum maupun kriteria air untuk keperluan prasarana/sarana rekreasi. Tingginya COD menujukkan bahwa tingginya kontaminan organik di kedua danau sehingga kedua danau.

Kata kunci : Kualitas Air, Buyan, Danau, Tamblingan 


\section{INTRODUCTION}

Bali was crowned the best world's destination in 2017 by Travelers Choice Award (TripAdvior, 2017). This achievement brings about positive as well as negative impacts. From an Economy perspective, the increased popularity of a tourist destination will potentially increase the number of tourist visits; however, on the other side, the development of tourism industry will have negative outcomes to the environment. According to The Travel and Competitiveness report 2015, Indonesia occupied 50th rank in Travel \& Tourism Competitiveness Index, and placed on 19th for natural resources. However, Indonesia had bad reputation on health and hygiene. Indonesia placed 109th on health and hygiene category and 134th rank on environmental sustainability, (World Economic Forum, 2015). In fact, tourism industry is sensitive towards environmental issues (Soemarwoto, 2001), such as pollution by industrial waste and household waste.

The current trend on tourism is ecotourism. Beside of its benefit on economy and local cultural sustainability, ecotourism supports environment conservation. Bali as one of the well-known international tourist destination has many potential tourism objects for ecotourism. Bali has, at least, 24 beach destinations, 4 lakes, 11 rivers/ waterfalls, and 5 hot springs; and those objects are potential to be nautical tourism destinations and landscape tourism.

Water pollution is one of the issue arising on new tourist destination development.
Times Indonesia (2016) reports that lakes in Bali is contaminated and undergoes sedimentation because of aquaculture activity, farming, and waste discharge from household and tourism industry. Based on STORET index study by Saputra, et.al (2017), water of Buyan Lake was classified as heavy polluted, while study by MiaDeviP (2016) using the same methodology reported that water of Tamblingan Lake was lightly contaminated. Contamination of lake water, in term of physical, chemical, and biological, does not only harm the community's health, but it also disturbs the aquatic ecosystem and the sustainability of tourism industry. The aim of this study was to examine the water quality of Buyan Lake and Tamblingan Lake in 2018 based on physical, chemical, and biological parameters and evaluated it according to Bali Governor Regulation no 16 Year 2016 on Management of Water Quality and Pollution Control.

\section{MATERIALS AND METHODS}

Descriptive cross sectional study was conducted in June 2018 and situated in Buyan Lake and Tamblingan Lake. Five water samples were taken purposively from five stations located near to residence/ access area to each Lake. The stations were selected based on characteristic of the surrounding area which was potential for pollutant discharged. 


\section{WMJ (Warmadewa Medical Journal), Vol. 5 No. 1, Mei 2020, Hal. 10}

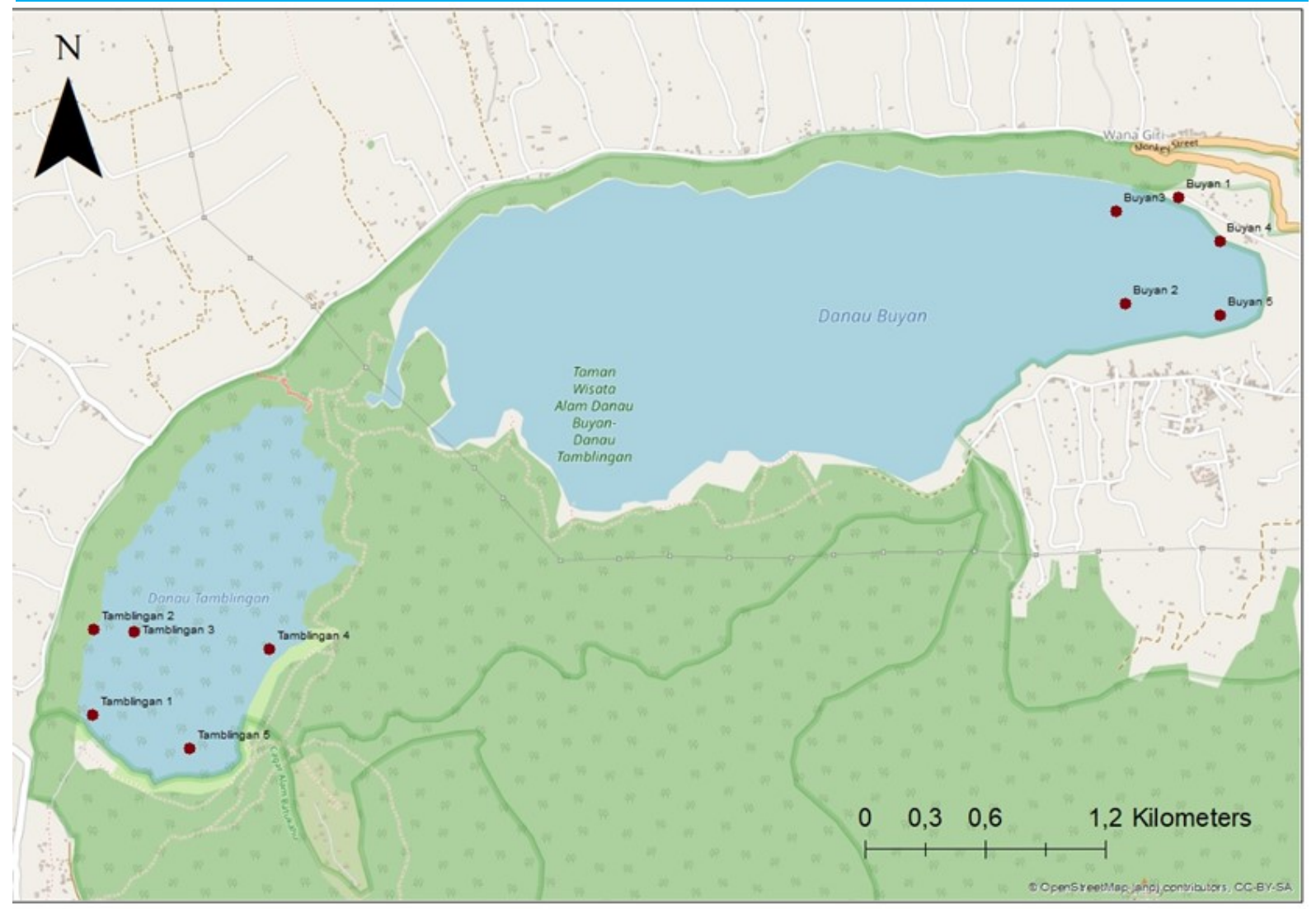

Figure 1. Location of sampling/stations

Physical parameters (temperature and dissolved solids) and $\mathrm{pH}$ were measured insitu using water quality checker. Meanwhile, other parameters such as Dissolved Oxygen (DO), Biochemical Oxygen Demand (BOD5), Chemical Oxygen Demand (COD), pH, phosphate, ammonia, nitrate, and heavy metals $(\mathrm{Cu}, \mathrm{Cd}, \mathrm{Pb})$ as well as biological parameters (coliform and fecal coliform) were assessed at Laboratorium Kesehatan Provinsi Bali. The analytical methods for those parameters were presented on Table 1. The water samples were kept in a cool box equipped with ice pack. The lag time between the water sampling and the analysis did not exceed 24 hours. The results were compared to the water quality standard based on Bali Governor Regulation no 16 Year 2016.
Table 1. Water Quality Analysis Methods

\begin{tabular}{|c|c|c|c|}
\hline No & Parameter & Satuan & Metode Analisa \\
\hline 1 & Copper $(\mathrm{Cu})$ & $\mathrm{mg} / \mathrm{l}$ & AAS \\
\hline 2 & Cadmium (Cd) & $\mathrm{mg} / \mathrm{l}$ & AAS \\
\hline 3 & Lead $(\mathrm{Pb})$ & $\mathrm{mg} / 1$ & AAS \\
\hline 4 & $\begin{array}{l}\text { Ammonia (NH3- } \\
\mathrm{N})\end{array}$ & $\mathrm{mg} / \mathrm{l}$ & Spectrophotometer \\
\hline 5 & Nitrate $\left(\mathrm{NO}_{3}-\mathrm{N}\right)$ & $\mathrm{mg} / \mathrm{l}$ & Spectrophotometer \\
\hline 6 & BOD & $\mathrm{mg} / \mathrm{l}$ & Titration \\
\hline 7 & COD & $\mathrm{mg} / \mathrm{l}$ & Titration \\
\hline 8 & DO & $\mathrm{mg} / \mathrm{l}$ & Titration \\
\hline 9 & Phosphate & $\mathrm{mg} / \mathrm{l}$ & Spectrophotometer \\
\hline 10 & $\mathrm{pH}$ & - & $\mathrm{pH}$ meter \\
\hline 11 & Dissolved Solids & $\mathrm{mg} / \mathrm{l}$ & TDS meter \\
\hline 12 & Temperature & ${ }^{\circ} \mathrm{C}$ & Thermometer \\
\hline 13 & MPN Coliform & $/ 100 \mathrm{ml}$ & Inoculation \\
\hline 14 & MPN Fecal coli & $/ 100 \mathrm{ml}$ & Inoculation \\
\hline
\end{tabular}




\section{RESULT AND DISCUSSION}

This study assessed water samples taken purposively from five stations in Buyan Lake and Tamblingan Lake. Allocation of the water quality monitoring site is the first and the important step in the design of the water quality monitoring. Subjectivity of deciding the location for water monitoring site may increase the number of stations needed and increase the error of station selection. Asadollahfardi (2015) stated that there are three approach in selecting macro location for sampling based on Sander method (1983), they are: allocation by the number of contributing tributaries, allocation by the number of pollutant discharges, and allocation by measures of BOD loadings. This study used approach that based on amount of potential pollutant being discharged reflected by characteristic of surrounding areas. The result of the water quality assessment is presented on Table 2 and Table 3.

Table 2. Result of Water Assesement of Buyan Lake

\begin{tabular}{|c|c|c|c|c|c|c|c|c|c|}
\hline \multirow{2}{*}{ PARAMETER } & \multirow{2}{*}{ SATUAN } & \multirow{2}{*}{ SD } & \multirow{2}{*}{ MIN } & \multirow{2}{*}{ MAX } & \multirow{2}{*}{ MEAN } & \multicolumn{4}{|c|}{ BAKU MUTU AIR * KELAS } \\
\hline & & & & & & I & II & III & IV \\
\hline Copper $(\mathrm{Cu})$ & $\mathrm{mg} / \mathrm{l}$ & $\mathrm{n} / \mathrm{a}$ & $\begin{array}{r}<0.015 \\
3\end{array}$ & $<0.0153$ & $<0.0153$ & 0.02 & 0.02 & 0.02 & 0.02 \\
\hline Cadmium $(\mathrm{Cd})$ & $\mathrm{mg} / \mathrm{l}$ & $\mathrm{n} / \mathrm{a}$ & $<0.001$ & $<0.001$ & $<0.001$ & 0.01 & 0.01 & 0.01 & 0.01 \\
\hline Lead $(\mathrm{Pb})$ & $\mathrm{mg} / \mathrm{l}$ & $\mathrm{n} / \mathrm{a}$ & $<0.03$ & $<0.03$ & $<0.03$ & 0.03 & 0.03 & 0.03 & 1 \\
\hline $\begin{array}{l}\text { Ammonia (NH3- } \\
\text { N) }\end{array}$ & $\mathrm{mg} / \mathrm{l}$ & 0.07 & 0.14 & 0.32 & 0.22 & 0.5 & N/A & N/A & N/A \\
\hline Nitrate (NO3-N) & $\mathrm{mg} / \mathrm{l}$ & 0.04 & 0.09 & 0.2 & 0.14 & 10 & 10 & 20 & 20 \\
\hline BOD & $\mathrm{mg} / \mathrm{l}$ & 0.64 & 1.52 & 3.06 & $2.19 * *$ & 2 & 3 & 6 & 12 \\
\hline COD & $\mathrm{mg} / \mathrm{l}$ & 28.7 & 9.8 & 88.56 & $49.18 * * *$ & 10 & 25 & 50 & 100 \\
\hline DO & $\mathrm{mg} / \mathrm{l}$ & 0.11 & 7.6 & 7.88 & 7.7 & 6 & 4 & 3 & 1 \\
\hline Phosphate & $\mathrm{mg} / 1$ & 0.23 & 0.06 & 0.53 & 0.2 & 0.2 & 0.2 & 1 & 5 \\
\hline $\mathrm{pH}$ & - & 0.13 & 7.78 & 8.1 & 8.01 & $6-9$ & $6-9$ & $6-9$ & $5-9$ \\
\hline Dissolved Solids & $\mathrm{mg} / \mathrm{l}$ & 11.67 & 126 & 149 & 138.4 & 1000 & 1000 & 1000 & 2000 \\
\hline Temperature & ${ }^{\circ} \mathrm{C}$ & 0.24 & 21.8 & 22.4 & 22.14 & Dev 3 & Dev 3 & Dev 3 & Dev 5 \\
\hline MPN Coliform & $/ 100 \mathrm{ml}$ & 36.33 & 5 & 90 & 25.2 & 1000 & 5000 & 10000 & 10000 \\
\hline MPN Fecal coli & $/ 100 \mathrm{ml}$ & 0.89 & 0 & 2 & 0.4 & 100 & 1000 & 2000 & 2000 \\
\hline
\end{tabular}

Note:

Values above are maximum limits, except for $\mathrm{pH}$ and DO

** quality standard class $2 ; * * *$ quality standard class $3 ; * * * *$ quality standard class 4

Table 3. Result of Water Assesement of Tamblingan Lake

\begin{tabular}{|c|c|c|c|c|c|c|c|c|c|}
\hline \multirow{2}{*}{ PARAMETER } & \multirow{2}{*}{ SATUAN } & \multirow{2}{*}{ SD } & \multirow{2}{*}{ MIN } & \multirow{2}{*}{ MAX } & \multirow{2}{*}{ MEAN } & \multicolumn{4}{|c|}{ BAKU MUTU AIR * KELAS } \\
\hline & & & & & & $\mathbf{I}$ & II & III & IV \\
\hline Copper $(\mathrm{Cu})$ & $\mathrm{mg} / \mathrm{l}$ & $\mathrm{n} / \mathrm{a}$ & $<0.0153$ & $<0.0153$ & $<0.0153$ & 0.02 & 0.02 & 0.02 & 0.02 \\
\hline Cadmium $(\mathrm{Cd})$ & $\mathrm{mg} / \mathrm{l}$ & $\mathrm{n} / \mathrm{a}$ & $<0.001$ & $<0.001$ & $<0.001$ & 0.01 & 0.01 & 0.01 & 0.01 \\
\hline Lead $(\mathrm{Pb})$ & $\mathrm{mg} / \mathrm{l}$ & $\mathrm{n} / \mathrm{a}$ & $<0.03$ & $<0.03$ & $<0.03$ & 0.03 & 0.03 & 0.03 & 1 \\
\hline $\begin{array}{l}\text { Ammonia (NH3- } \\
\text { N) }\end{array}$ & $\mathrm{mg} / 1$ & 0.06 & 0.02 & 0.15 & 0.1 & 0.5 & N/A & N/A & N/A \\
\hline Nitrate (NO3-N) & $\mathrm{mg} / \mathrm{l}$ & 0.1 & 0.33 & 0.56 & 0.43 & 10 & 10 & 20 & 20 \\
\hline BOD & $\mathrm{mg} / \mathrm{l}$ & 0.24 & 1.19 & 1.81 & 1.61 & 2 & 3 & 6 & 12 \\
\hline COD & $\mathrm{mg} / \mathrm{l}$ & 17.93 & 39.3 & 78.74 & $62.92 * * * *$ & 10 & 25 & 50 & 100 \\
\hline DO & $\mathrm{mg} / 1$ & 0.08 & 7.46 & 7.69 & 7.57 & 6 & 4 & 3 & 1 \\
\hline Phosphate & $\mathrm{mg} / \mathrm{l}$ & 0.19 & 0.06 & 0.53 & $0.23 * *$ & 0.2 & 0.2 & 1 & 5 \\
\hline $\mathrm{pH}$ & - & 0.05 & 8.35 & 8.49 & 8.44 & $6-9$ & $6-9$ & $6-9$ & $5-9$ \\
\hline Dissolved Solids & $\mathrm{mg} / \mathrm{l}$ & 0.71 & 95 & 97 & 96 & 1000 & 1000 & 1000 & 2000 \\
\hline Temperature & ${ }^{\circ} \mathrm{C}$ & 0.29 & 22.2 & 22.9 & 22.48 & Dev 3 & Dev 3 & Dev 3 & Dev 5 \\
\hline MPN Coliform & $/ 100 \mathrm{ml}$ & 7090 & 33 & 16000 & $3319 * *$ & 1000 & 5000 & 10000 & 10000 \\
\hline MPN Fecal coli & $/ 100 \mathrm{ml}$ & 3 & 0 & 5 & 2 & 100 & 1000 & 2000 & 2000 \\
\hline
\end{tabular}


Note:

Values above are maximum limits, except for $\mathrm{pH}$ and DO

** quality standard class $2 ; * * *$ quality standard class $3 ; * * * *$ quality standard class 4

\section{Physical Parameters}

Assessment on temperature and dissolved solids showed that the water of Buyan Lake and Tamblingan Lake met the criteria for water quality standard class 1 . The temperatures indicated normal condition, varied according to measurement time $\left( \pm 22^{\circ} \mathrm{C}\right.$, natural). The accepted deviation for temperature variance is $3{ }^{\circ} \mathrm{C}$ and both lakes showed deviation less than $1{ }^{\circ} \mathrm{C}$. The water temperature plays significant role on the growth of the lake biota. According to Tatangindatu, et al (2013), the optimum water temperature for supporting aquatic life is aroound $28-32{ }^{\circ} \mathrm{C}$.

According to Vigil (2003), cool/cold water has higher natural affinity to oxygen molecule compared to warm water. Correlation between temperature and dissolved oxygen level suggests that the higher the water temperature, the lower the level of its dissolved oxygen. In addition, temperature also affects the rate of chemical and biological reaction. The increased rate of chemical reaction induced by the temperature, along with low level of dissolved oxygen, will initiate stress of water organisms. Similarly Effendi (2003) stated that the increase of temperature will increase viscosity, chemical reaction, evaporation, volatility, and cause decrease in dissolved gases $\left(\mathrm{O}_{2}, \mathrm{CO}_{2}\right.$, $\mathrm{N}_{2}, \mathrm{CH}_{4}$, etc.). The optimum water temperature for phytoplankton growth is approximately $20{ }^{\circ} \mathrm{C}-30{ }^{\circ} \mathrm{C}$.

Dissolved solids level in water of Buyan Lake and Tamblingan Lake met the water quality standard of class 1 with value ranged from $126-149 \mathrm{mg} / \mathrm{l}$ and $95-97 \mathrm{mg} /$ 1 , respectively. This findings were similar to survey of Great Lake (65 -227 mg/l) (World Health Organization 2003). Dissolved solids in water describes the concentration of inorganic salts and small amount of dissolved organic matters in water. Inorganic substances might come from mineral and salt deposits released from soil and carried away into water. While organic substances might be the products of vegetation decomposition. The presence of high level of TDS in water usually does not cause health problems, but it can affect water aesthetic. High level of TDS can affect water turbidity as well as its taste.

\section{Chemical Parameters}

Acids and Bases could be harmful to health and aquatic life. These chemical are corrosive/irritant and might be toxic for aquatic organism. Type and amount of dissolved minerals, gas, and aquatic organisms determine the natural $\mathrm{pH}$ level of a waterbody. According to Effendi (2003), $\mathrm{pH}$ is also highly associated with carbondyoxide.The higher the $\mathrm{pH}$ values, the lower free carbondyoxide level. In this study, water $\mathrm{pH}$ of Buyan Lake was around 7.78 - 8.10, whereas, water $\mathrm{pH}$ of Tamblingan Lake had slightly higher range, which was 8.35 8.49. The values of both lakes met the criteria for water quality standard class 1 .

The level of heavy metals $(\mathrm{Cu}, \mathrm{Cd}$, and $\mathrm{Pb}$ ) were much lower than the maximum limit for water quality standard 1 . This finding is in contrast to the study by Arthana (2007) which stated that cadmium and lead levels from water sources around Bedugul exceeded the water quality standard. Arthana (2007) found that Pb level in water spring of Buyan was $0.032 \mathrm{mg} / \mathrm{l}$ which is slightly higher than the quality standard $(0.03 \mathrm{mg} / \mathrm{l})$. According to Soemarwoto (2001) the significant source of lead contamination is from transportation activities. The fuel from petrol can be released and contamintes the soil through air mediator. The discrepency of these findings might occur because the difference in study time and sampling locations as the article of Arthana (2007) stated that his sampling locations was done in water sources near to traffic roads.

Other parameters meeting the quality standard class 1 was nitrogen, both as ammonia and nitrate. Ammonia level in water samples of Tamblingan Lake 
$(0.10 \pm 0.06 \mathrm{mg} / \mathrm{l})$ was slightly lower compared to water of those Buyan Lake $(0.22 \pm 0.07 \mathrm{mg} / \mathrm{l})$. The presence of higher level of ammonia than its geogenic might indicate fecal contamination (Bartram, Ballance, \& Organization, 1996). Ammonia could undergoes oxidation by microorganism and turn into nitrate and nitrate. In this study, the levels of nitrite in water of Buyan Lake and Tamblingan Lake were low $(<10$ $\mathrm{mg} / \mathrm{l})$, which were $0.14 \pm 0.04 \mathrm{mg} / \mathrm{l}$ dan $0.43 \pm 0.10 \mathrm{mg} / \mathrm{l}$, respectively. This similar finding was described by Purnamawati, et al (2018) in her study of nitrate and phosphate level in Buyan Lake and its relation to watermoss growth. Of four time measurements, Purnamawati, et al (2018) found that nitrate level was significantly lower compared to its quality standard class 1 $(<10 \mathrm{mg} / \mathrm{dl})$ where the lowest nitrate level was $(0.086 \mathrm{mg} / \mathrm{dl})$ and the highest level was $4.89 \mathrm{mg} / \mathrm{dl}$. In spite of that, Tatangindatu (2013) explains that nitrate level more than $0.2 \mathrm{mg} /$ liter is enough to cause eutrofication and later invoke blooming.

Phosphate level in Buyan Lake was found exactly on the maximum threshold of standard quality class $1(2.0 \mathrm{~g} / \mathrm{l})$, while the phosphate level of Tamblingan lake was slightly higher than the maximum level (2.3 $\mathrm{mg} / \mathrm{l})$. Higher level of phosphate compared to environmental standard was also found by Purnamawati, et al (2018) and the study suggested that the aquaculture was responsible for the contamination. Phosphate is a common component of fertilizer and organic waste from industry and households. Phosphate is an important element for vegetation growth, however, its high concentration will cause eutrophication (Penn \& Bowen, 2017).

Organic pollutants mostly come from the waste produced by household, farming, and industry. The measurement of organic material in lake water was carried out by assessing the levels of BOD and COD. The BOD is measured based on the biodegradation process of organic compounds by bacteria in the water, while COD measures the organic materials in the water, both biodegradable and non- biodegradable organic materials, including toxic compounds (heavy metals and cyanide) (Vigil, 2003). This study showed that BOD level of Tamblingan Lake still met the specification for water standard quality class 1, while BOD level of Buyan Lake only met criteria for standard quality 2 . In contrast to BOD results, COD level of Tamblingan Lake was classified into standard quality 4. While COD level of Buyan Lake was classified into standard quality 3 . The high levels of COD indicates the high level of oxidizable organic materials in the water and this condition can lower the dissolved oxygen. In spite of that, the average dissolved oxygen (DO) in both lakes showed acceptable level for water standard quality class 1 .

\section{$\underline{\text { Biological Parameters }}$}

Biological parameters of Buyan Lake met the specification of water quality standard class 1 . While water assessment of Tamblingan Lake showed high average of MPN coliform (3319 MPN/100 ml) with high standard deviation $( \pm 7090 \mathrm{MPN} / 100$ $\mathrm{ml}$ ). Investigation on data from each station revealed that four stations of Tamblingan Lake had MPN coliform less than 1000 MPN/100 ml, while one station showed really high MPN count (16.000 MPN/100 $\mathrm{ml})$. The presence of coliform does not necessary mean contamination of fecal. The type of farming around Tamblingan Lake is mostly seasonal plants such as hydrangea flowers, strawberry, carrot, and vegetables which normally use chemical fertilizer; thus, the possibility of contamination from organic/biofertilizer was low. In extreme situation, high count of coliform could be seen when thermotolerant coliforms indicates low, even zero count (Bartram et al., 1996). That phenomena was observed in this study; the high count of coliform in station 5 of Tamblingan Lake was not consistent with fecal coliform count nor ammonia level. High number of soil natural coliforms in the area could have contributed to the high count of fecal coliform in the station 5 or the area might have optimum condition for the growth of certain coliforms. 


\section{CONCLUSIONS}

Generally, water from Buyan Lake and Tamblingan Lake did not meet the criteria for drinking-water quality neither meet the criteria for recreational purposes. Of 14 water quality parameters, samples of Buyan Lake showed two parameters (BOD and COD) exceeded the maximum accepted concentration for quality standard class 1, while samples of Tamblingan Lake showed three parameters (phosphate, coliform, and COD) unqualified for quality standard class 1. The high level of COD suggests high organic contaminants in both lakes, thus the lakes did not meet criteria for water quality class 1 (potable water) nor criteria for water quality standard class 2 (recreational). Further study is needed to identify specific causes of the high level of COD in both lakes. Authors also suggest measuring overall water quality of both lakes using water quality index.

\section{REFERENCES}

1. Arthana, I. W. (2007). Studi Kualitas Air Beberapa Mata Air di Sekitar Bedugul, Bali (The Study of Water Quality of Springs Surrounding Bedugul, Bali). Bumi Lestari Journal of Environment, 7(1)

2. Asadollahfardi, G. (2015). Water quality management: assessment and interpretation, Springer.

3. Bartram, J., Ballance, R., \& Organization, W. H. (1996). Water quality monitoring: a practical guide to the design and implementation of freshwater quality studies and monitoring programs.

4. Effendi, H. (2003). Telaah kualitas air, bagi pengelolaan sumber daya dan lingkungan perairan: Kanisius.

5. MiaDeviP, P. (2016). Studi Kualitas Air Terhadap Tata Guna Lahan Di Danau Tamblingan Desa Munduk, Kecamtan Banjar, Kabupaten Buleleng, Bali. Universitas Brawijaya.

6. Peraturan Gubernur Bali No 16 Tahun 2016 Tentang Baku Mutu Ling- kungan Hidup dan Kriteria Baku Kerusakan Lingkungan Hidup, (2016).

7. Penn, C. J., \& Bowen, J. M. (2017). Design and Construction of Phosphorus Removal Structures for Improving Water Quality: Springer.

8. Purnamawati, N. W. I., Arthana, I. W., \& Saraswati, S. A. (2018). Kandungan Nitrat, Fosfat Dan Pertumbuhan Biomassa Basah Kiambang (Salvinia molesta) Di Perairan Danau Buyan, Buleleng, Bali. Journal of Marine and Aquatic Sciences(1), 55$63 \% \mathrm{~V} \quad 55 . \quad$ doi:10.24843/ jmas.2019.v05.101.p07

9. Regina Wisata. DAFTAR LENGKAP TEMPAT WISATA DI BALI TERBARU. Retrieved from https:// reyginawisataindonesia.blogspot.com/2016/07/daftarlengkap-tempat-wisata-di-baliterbaru.html

10. Saputra, I. W. R. R., Restu, I. W., \& Pratiwi, M. A. (2017). Analisis Kualitas Air Danau Sebagai Dasar Perbaikan Manajemen Budidaya Perikanan di Danau Buyan Kabupaten Buleleng, Provinsi Bali. ECOTROPHIC: Jurnal Ilmu Lingkungan (Journal of Environmental Science), 11(1), 1-7.

11. Soemarwoto, O. (2001). Atur-dirisendiri: paradigma baru pengelolaan lingkungan hidup: pembangunan ramah lingkungan: berpihak pada rakyat, ekonomis, berkelanjutan: Gadjah Mada University Press.

12. Tatangindatu, F., Kalesaran, O., \& Rompas, R. (2013). Studi parameter fisika kimia air pada areal budidaya ikan di Danau Tondano, Desa Paleloan, Kabupaten Minahasa. E-Journal Budidaya Perairan, 1(2).

13. TripAdvior. (2017). The Very Best of TravelChosen by Millions of Travelers. Retrieved from https:// www.tripadvisor.com/

TravelersChoice

14. Vigil, K. M. (2003). Clean Water: AN Introduction to Water Quality and Water Pollution Control (2nd ed.). USA: Oregon State University Press. 
15. World Economic Forum. (2015). The Travel \& Tourism Competitiveness Report 2015. Retrieved from Geneva:

16. World Health Organization (2003). "Background document for develop- ment of WHO Guidelines for Drinking-water Quality." World Health Organization 20: 4-6. 